\title{
The Effect of Some Soil Amendments (Manure and Biochar) on the Bioaccumulation Capacity of Hexavalent Chromium by Two Species of \\ (Salicornia Persica) and (Salicornia Perspolitana) From Contaminated Soil
}

\section{Fahime Ashrafi}

Ferdowsi University of Mashhad

Ava heidari ( $\square$ ava.heidari@yahoo.com )

Ferdowsi University of Mashhad

Mohammad Farzam

Ferdowsi University of Mashhad

Alireza Karimi

Ferdowsi University of Mashhad

Malihe Amini

University of Jiroft

\section{Research Article}

Keywords: Soil contamination, Salicornia, phytoremediation, chromium.

Posted Date: June 1st, 2021

DOI: https://doi.org/10.21203/rs.3.rs-439629/v1

License: (c) (1) This work is licensed under a Creative Commons Attribution 4.0 International License.

Read Full License 


\section{The effect of some soil Amendments (manure and biochar) on the} Bioaccumulation capacity of Hexavalent Chromium by two species of (Salicornia persica) and (Salicornia perspolitana) from Contaminated soil

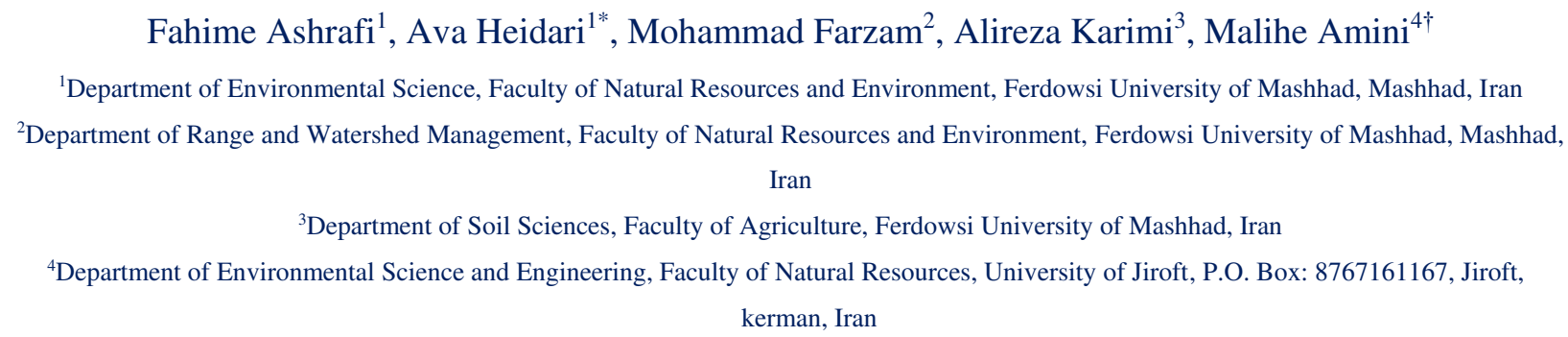

Abstract: Heavy metals are among the most dangerous contaminants in the environment. Application of organic compounds and plant species with the ability to accumulate and stabilize heavy metal in their organs is the best option for remediation of these elements in the soil. Therefore, this study aimed to investigate the effects of manure and biochar on the accumulation of heavy metals by Salicornia species. Two species of Salicornia, including S. persica and $S$. perspolitana, were cultivated outdoor in experimental pots. The effects of experimental treatments, including hexavalent chromium concentrations, manure, and biochar on the two studied species, were investigated. The results indicated a significant effect $(\mathrm{P}<0.05)$ of biochar on the accumulation of heavy metals by two species, $S$. persicaand $S$. perspolitana, so that chromium concentrations in the roots and shoots were 258 and $5.41 \mathrm{mg} / \mathrm{kg}$, respectively. Also, chromium accumulations under manure treatments in the roots and shoots were 334.34 and 9.79 $\mathrm{mg} / \mathrm{kg}$, respectively. Plant dry weight and height for both species in manure treatment were higher than control and biochar treatments. S. persica showed higher growth than S. perspolitana species. The content of photosynthetic pigments in both S.persica and S. perspolitana species

*Corresponding author. heidari@um.ac.ir, ava.heidari@yahoo.com, Phone number: +9838805471

${ }^{\dagger}$ Co- Corresponding author: m.amini@ujiroft.ac.ir 
27 under biochar treatment was higher than control and manure treatments. In general, one can

28 conclude that the accumulation of chromium in S. perspolitana was higher than in S. persica, and

29 the application of biochar and manure amendments could stabilize chromium in soil and reduce

30 chromium accumulation in both S. persica and S. perspolitana species.

31 Keywords: Soil contamination, Salicornia, phytoremediation, chromium.

\section{1. Introduction}

33 Increased agricultural activities, as well as industrialization in recent decades, have significantly

34 resulted in the accumulation of various contaminants in the environment, especially in soil and

35 water. These contaminants enter into the environment through mining operations, discharge of

36 industrial effluents, pesticide-based agriculture, fertilizers, etc., and are challenging and

37 problematic due to harmful effects on soil biological systems (Edao 2017). Removal of heavy

38 metals from soil could be a severe issue as heavy metals are special contaminants, which in

39 many cases, could remain in the soil for hundreds (even thousands) of years. Several methods

40 have been documented for removing heavy metals from contaminated soils. Despite being

41 efficient, conventional technologies are costly, time-consuming, and environmentally

42 destructive. Phytoremediation is defined as applying of various plants to reduce the

43 concentration of heavy metals in the soil. Generally, bioremediation has been considered as a

44 cost-effective and environmentally friendly method (Yao et al. 2012). Species store and

45 accumulate high concentrations of heavy metals in their tissues without being poisoned by that

46 metals. During the phytoremediation process, metals are effectively removed from the soil. The

47 efficiency of the phytoremediation process is dependent on the plant functioning as well as the

48 effective transfer of metals from the plant roots to the shoots. Plants that accumulate

49 considerable amounts of metal usually have small shoots, so the critical point for increasing the 
50 efficiency of the phytoremediation process is how to change plant biomass to enhance metal

51 uptake (Evangelou et al. 2007). Biochar is a porous carbon product obtained from the pyrolysis

52 of plant-derived organic matter (tree bark, rice husk, pinewood, etc.) or non-plant-derived

53 biomass (cattle manure, poultry manure, etc.) with high cation exchangeable capacity and

54 alkaline properties that improve soil structure. The addition of biochar to soil leads to increased

55 soil biological activities, thereby improved crop yield(Bashir et al. 2018). In addition to biochar,

56 applying of some other materials such as animal manure in soils could also increase the

57 phytoremediation efficiency. Organic fertilizers, especially animal manures, contain large

58 amounts of organic matter compared to chemical ones, which can provide nutrient sources such

59 as nitrogen, phosphorus, and potassium overtime for the plant and improve soil physical,

60 chemical, and biological properties. Increased organic matter in soils leads to the formation of

61 aggregates and improves soil moisture-holding capacity, hydraulic conductivity, bulk density,

62 degree of compaction, fertility, and soil resistance to water and wind erosion (Zebarth et al.

63 1999). A study by Al-Wabe et al.(Al-Wabel et al. 2015) showed that the application of biochar

64 improved the growth of maize (Zea mays L.) and increased the soil water holding capacity of the

65 soil. Biochar also leads to alkaline properties in the soil, and this effect varies depending on

66 biochar characteristics, production temperature, and its raw materials.

67 Few plant species, including Sutera fodina, Dicoma niccolifera, and Leptospermum scoparium,

68 have been reported to have the ability to accumulate high concentrations of chromium in their

69 tissues. Also, mustard (Brassica juncea) and sunflower (Helianthus annus L.) have been reported

70 to accumulate high concentrations of chromium in their tissues(Shahandeh \&Hossner 2000).

71 Coupe et al.(Coupe et al. 2013) compared the ability of three plant species, namely Eucalyptus

72 camaldeulensis, Brassica juncea, and Medicago sativum, to uptake copper, zinc, and 
73 chromium from soil and stated that Eucalyptus camaldeulensis had the highest capability to

74 uptake these contaminants from the soil. Salicornia, a halophyte and salt-tolerant plant, serves as

75 a suitable plant for phytoremediation of heavy metals due to its characteristic roots and the

76 ability to stabilize metals (Van Oosten et al. 2015).

77 Several studies have been carried out on the phytoremediation ability of Salicornia plant species

78 for removal of heavy metals other than chromium, but for the first time, we aimed to investigate

79 the ability of Salicornia persica and Salicornia perspolitana in phytoremediation of chromium-

80 contaminated soils. To do this, we studied the effect of manure and biochar on the capacity of the

81 two mentioned species to accumulate chromium in their tissues from contaminated soil. In this

82 regard, experimental treatments including hexavalent chromium concentrations, manure , and 83 biochar.

\section{2. Materials and methods:}

\section{$85 \quad 2.1 \quad$ Experiments}

86 All steps of this research were performed in 2019-2020 in the laboratory and growth chamber of

87 Faculty of Natural Resources and Environment, the Ferdowsi University of Mashhad, Iran, 88 located at $25 \mathrm{~km}$ apart from northeast of Mashhad city (59 31' 16" E and 36 29' 92" N). The 89 soil samples were taken from a 0-40 cm and passed through a 2-mm sieve after air-drying.

\subsection{Determination of soil physical and chemical properties}

91 Soil texture was characterized by the hydrometric method using a soil texture triangle. Soil $\mathrm{pH}$ 92 and EC (electrical conductivity) were measured using pH-meter (20+, Crison, Spain) and EC93 meter (4510, Jenway, England) devices, respectively. Soil organic carbon was determined by the 94 dry combustion method (Park et al. 2017). Total nitrogen was measured using a Kajeldal (V50) 95 device. Soil available phosphorus was measured according to the Olsen method (1954) using a 
96 spectrophotometer (model DR 5000) at the wavelength of $660 \mathrm{~nm}$. Available potassium was

97 determined using the ammonium acetate method and photoelectric flame photometer (Jenway

98 PFP7).

\subsection{Determination of physical and chemical properties of manure and biochar}

100 The completely rotten manure used in this study was prepared from the greenhouse of Ferdowsi

101 University of Mashhad, Iran. The applied biochar was a mixture of the wood obtained from

102 eucalyptus, poplar , and ironwood prepared at $500^{\circ} \mathrm{C}$ at the laboratory of Tarbiat Modares

103 University, Iran. Before performing the experimental treatments, manure and biochar samples

104 were analyzed using conventional laboratory methods previously applied to measure the soil

105 samples. Calcium and sodium contents were determined by inductively coupled plasma

106 spectroscopy (ICP-OES) (model ICP-OES, SPECTRO ARCOS-76004555) and the percentages

107 (\%) of carbon, nitrogen, hydrogen, oxygen, and sulfur in the biochar using elemental analysis

108 (FLASH EA 1112 SERIES, Themo Finnigan).

1092.4 Preparation of soil samples

110 The soil in the natural habitat was characterized by clay-sandy loam texture and an EC of 1800

$111 \mu \mathrm{s} / \mathrm{cm}$, and we prepared the soil samples containing sand, $\mathrm{NaCl}$, and hexavalent chromium

112 (concentrations of $0-150 \mathrm{mg} / \mathrm{kg}$ ) in order to simulate the soil of the natural site in terms of

113 texture and salinity. After implementing treatments, the soil samples were completely

114 homogenized and mixed, and stored in plastic bags. The treated soil samples were then

115 moistened to the field capacity and kept at this constant moisture level for 15 days in order to

116 simulate the soil contamination with heavy elements somewhat similar to the natural conditions

117 in the contaminated fields. Then, biochar and manure were added (10 $\mathrm{g}$ of amendment per $1 \mathrm{~kg}$ 
118 of soil) to each sample of the contaminated soils with three replicates. Soil samples were mixed

119 well for each pot to make soil conditions homogeneous in all parts.

\subsection{Germination of Salicornia seeds}

122 Metal chromium was added to the seeds of $S$. persica, and S. perspolitana species as a factorial

123 design in 3 replicates and seven concentration levels $(0,5,10,15,50,100$, and $150 \mathrm{mg} / \mathrm{l})$. Inside

124 each Petri dish, there were $10 \mathrm{ml}$ of hexavalent chromium solution at different concentrations as

125 well as 25 seeds. Then, all the petri dishes were incubated in a growth chamber at a temperature

126 of $25-30{ }^{\circ} \mathrm{C}$ with a photoperiod of $16 \mathrm{~h}$ of light and eight $\mathrm{h}$ of darkness. The seeds with a radicle

127 of $2 \mathrm{~mm}$ were considered as a germinated seed, and all the germinated seeds were counted on a

128 daily basis. Because no germination was observed from the 14th to the 16th day, the counting

129 was stopped on the 16th day. Also, the length of root and stem, as well as the length of seedling

130 (the sum of root length and stem length) was measured on the 16th day by an mm-sized ruler.

131 Germination percentage, germination rate, seedling length, seed vigor index , and allometric

132 index were calculated based on the equations 2-1 to 2-5, respectively(Saberi et al. 2010).

$$
G P=\frac{G}{N} \times 100
$$

134

$$
G S=\Sigma \frac{n i}{D i}
$$

$$
T L=S L+R L
$$

$136 \quad S V I=\frac{G R \times M e a n(S I+R L)}{100}$

$137 \quad$ Allometry $=\frac{\text { root length }}{\text { shoot lrngth }}$

138 Where, GP: germination percentage, G: the final number of germinated seeds N: number of 139 seeds sown (25 seeds in this study), GS: germination rate, ni: number of germinated seeds on 
140 counting days and Di: number of days in the experiment, TL: total seedling length, SVI: seed

141 vigor index, SL: stem length, RL: root length

\section{$142 \quad 2.6 \quad$ Cultivation of seeds}

143 When the soil contamination period ended up, and after adding manure and biochar to the 144 contaminated soil, 12 seeds of Salicornia were planted at a depth of $0.5 \mathrm{~cm}$ for each pot. After 145 one month, due to lack of seed germination observed in the contaminated soil, the seedlings of $S$. 146 persica and $S$. perspolitana were planted in a mixture of coco-peat (Coir) and perlite (1: 1) in the 147 growth chamber at a temperature of $25-30{ }^{\circ} \mathrm{C}$ and a photoperiod characterized by $16 \mathrm{~h}$ of light 148 and eight $\mathrm{h}$ of darkness. In the early stages of the seedlings' growth, Hoagland nutrient solution 149 was used every two weeks. After five months, seedlings of the same size were selected and 150 transferred to the contaminated soil in the pots. The pots were incubated in contaminated soil 151 from June to November. The seedlings were died at 50, 100 , and $150 \mathrm{mg} / \mathrm{kg}$, but survived at 0 , 1525,10 , and $15 \mathrm{mg} / \mathrm{kg}$ concentrations. The seedlings of $S$. persica and $S$. perspolitana were 153 harvested after six months of growth in the contaminated soil. After harvesting, the roots and 154 shoots were washed first with tap water and then with distilled water.

\section{$155 \quad 2.7$ Measurement of plant growth and morphological traits}

156 Root and shoot weight were calculated in $\mathrm{g}$ per $\mathrm{kg}$ pot. The content of photosynthetic pigments ,

157 including chlorophyll $a$ and $b$, and carotenoids in S. persica and S. perspolitana were read by 158 UV-Visible spectrophotometer (HACH, DR 5000, America). The total phenolic content of the 159 samples was calculated as gallic acid equivalent (mg of gallic acid per $\mathrm{g}$ of dry matter). The 160 concentration of hexavalent chromium was determined by a UV-Visible spectrophotometer 161 (HACH, DR 5000, America). 
164 Scanning electronic microscopy (SEM) (Model VP 1450, LEO - Germany) was applied for 165 determining the morphology of the materials used in this study. Experimental treatments 166 included plant species (2 levels), the addition of metal hexavalent chromium in 7 levels (zero, 5, 16710 and 15, 50, 100 and $150 \mathrm{mg} / \mathrm{kg}$ ), and soil amendments in 3 levels (manure, biochar , and 168 control). The total number of experimental units (number of pots) was 126. A factorial 169 experiment in the form of a completely randomized design with three replicates was used to 170 evaluate the results of this study. Statistical analysis of data including ANOVA was performed in

171 Minitab v.16 software, and Tukey test was applied for comparison of means (both the main 172 effects and interactions) at the significance level of 0.05 .

\section{3. Results}

$174 \quad 3.1 \quad$ Physical and chemical properties of soil, cattle manure, and biochar

175 The soil used in this study was characterized by heavy texture, low salinity (EC of 1.8), and 176 approximately alkaline $\mathrm{pH}$ (8.14). The soil texture was clayey-sandy loam with the organic 177 carbon content of $2.56 \%$. The percentages of organic carbon, total nitrogen, phosphorus, 178 potassium in the manure were $56 \%, 2.95 \%, 0.62 \%$, and $0.94 \%$, respectively. The values for 179 carbon, hydrogen, nitrogen, oxygen and sulfur in biochar were $73.41 \%, 2.71 \%, 0.37 \%, 23.51 \%$ 180 and $0 \%$, respectively. The results of heavy metal analysis tests showed that the concentration of 181 hexavalent chromium in the soil was $2.91 \mathrm{mg} / \mathrm{kg}$, while there was no hexavalent chromium in 182 manure and biochar.

\section{$183 \quad 3.2$ Scanning electron microscopy (SEM)}

184 Figure 1 shows the Scanning Electron Microscopy images (SEM) of the biochar surface. As 185 shown, biochar is characterized by a large surface area and a relatively regular network of 
186 honeycomb-shaped pores on its surface, which leads to the absorption of heavy metals. Also, this

187 honeycomb network represents a carbon skeleton in the biochar structure(Ghani et al. 2013).
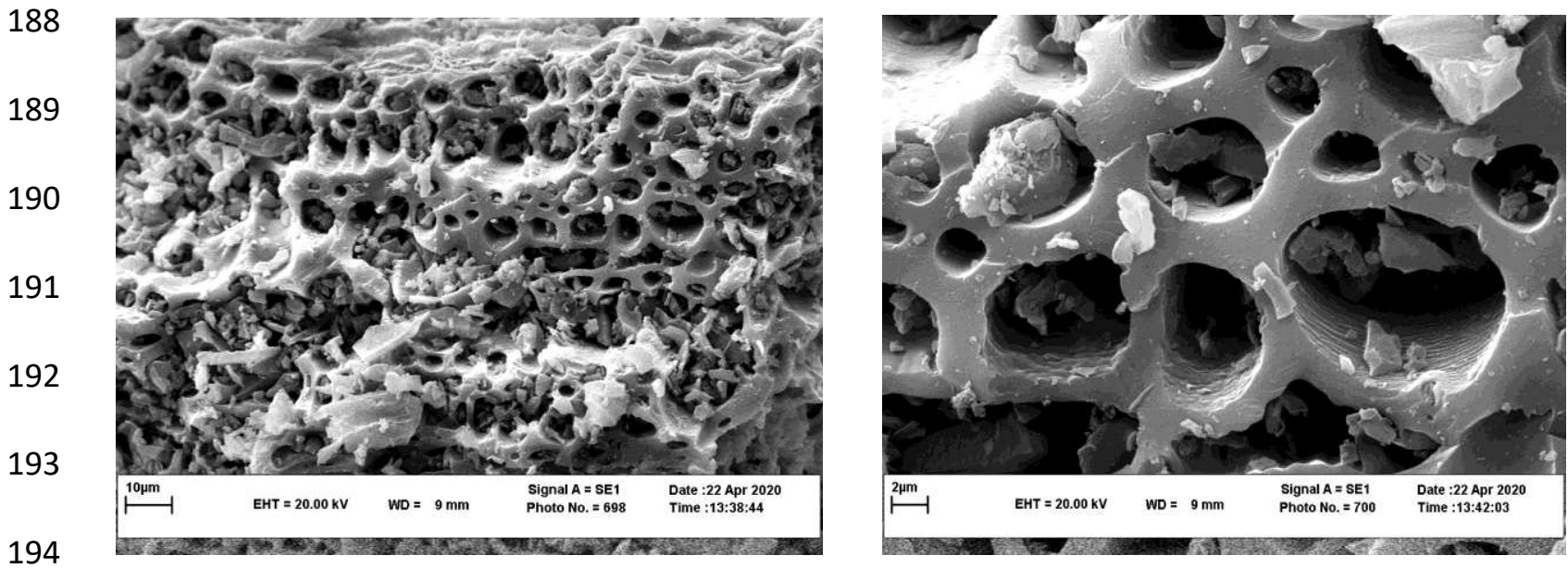

Figure 1. Scanning electron microscopy (SEM) of biochar surface

196

\subsection{Effect of different concentrations of hexavalent chromium on germination traits of $S$.} persica and S. perspolitana

199 The results of the effect of different concentrations of chromium on the germination percentage

(\%) and rate, and root length, shoot length, and seedling length in the two studied species shown

201 in Table 1 indicated a higher resistance of $S$. persica compared to $S$. perspolitana against metal 202 hexavalent chromium stress so that all germination traits declined with increasing the 203 concentration of chromium from the control $(0 \mathrm{mg} / \mathrm{l})$ to $150 \mathrm{mg} / \mathrm{l}$, and eventually led to plant 204 dying. 
Table 1. Results of comparison of the means related to simple effect of different concentrations

210 of chromium on germination traits of S. persica and S. perspolitana

\begin{tabular}{|l|l|l|l|l|l|}
\hline Treatment & $\begin{array}{l}\text { Germination } \\
\text { percentage }\end{array}$ & $\begin{array}{l}\text { Germination } \\
\text { rate }\end{array}$ & $\begin{array}{l}\text { Stem } \\
\text { length }\end{array}$ & $\begin{array}{l}\text { Root } \\
\text { length }\end{array}$ & $\begin{array}{l}\text { Seedling } \\
\text { length }\end{array}$ \\
\hline species & & & & & \\
\hline S. persica & $58.89^{\mathrm{a}}$ & $1.05^{\mathrm{a}}$ & $10.11^{\mathrm{a}}$ & $1.088^{\mathrm{a}}$ & $21.11 \mathrm{a}$ \\
\hline S. perspolitana & $50.44^{\mathrm{b}}$ & $0.900^{\mathrm{b}}$ & $8.16^{\mathrm{b}}$ & $1.080^{\mathrm{a}}$ & $9.24^{\mathrm{b}}$ \\
\hline $\begin{array}{l}\text { Different } \\
\text { concentrations } \\
\text { chromium }\end{array}$ & & & & & \\
\hline $\mathbf{C r}_{\mathbf{0}}$ & & & & & \\
\hline $\mathrm{Cr}_{5}$ & & & & & \\
\hline $\mathbf{C r}_{15}$ & $67.68^{\mathrm{a}}$ & $1.22^{\mathrm{a}}$ & $11.38^{\mathrm{a}}$ & $1.91^{\mathrm{a}}$ & $13.3^{\mathrm{a}}$ \\
\hline $\mathbf{C r}_{\mathbf{5 0}}$ & $64.67^{\mathrm{b}}$ & $1.15^{\mathrm{ab}}$ & $11.29^{\mathrm{a}}$ & $1.50^{\mathrm{b}}$ & $12.83^{\mathrm{a}}$ \\
\hline $\mathrm{Cr}_{\mathbf{1 0 0}}$ & $60.67^{\mathrm{b}}$ & $1.08^{\mathrm{b}}$ & $9.60^{\mathrm{b}}$ & $0.91^{\mathrm{c}}$ & $10.51^{\mathrm{b}}$ \\
\hline $\mathbf{C r}_{150}$ & $52.67^{\mathrm{c}}$ & $0.94^{\mathrm{c}}$ & $8.89^{\mathrm{bc}}$ & $0.85^{\mathrm{c}}$ & $9.75^{\mathrm{bc}}$ \\
\hline
\end{tabular}

211 Different letters indicate statistically significant differences at $\mathrm{P}>0.05$.

3.4 Effect of different concentrations of hexavalent chromium, manure, and biochar on the plant height of two species S. persica and S. perspolitana

As seen in table 2, the effect of different concentrations of chromium on the plant height of the related to $\mathrm{Cr}_{0}$ (no chromium) and $\mathrm{Cr}_{15}$ (chromium concentration of $15 \mathrm{mg} / \mathrm{g}$ ) with corresponding

218 heights of 45.33 and $27 \mathrm{~cm}$, respectively. The height reported for S. persica was $6.42 \%$ higher

219 than S. perspolitana, which can be attributed lower accumulation of chromium in S. persica 220 tissues. As shown in the table, the effect of different amendments on the height of the two 221 studied plant species was also significant. Manure and biochar treatments indicated an increased 222 height by $22.42 \%$ and $12.51 \%$, respectively, compared to the control treatment. 
225 Table 3. Results of mean comparison of interaction effects between different concentrations of

226 chromium, manure and biochar on the height of S. persica and S. perspolitana

\begin{tabular}{|c|c|c|c|}
\hline treatments & $\begin{array}{l}\text { Plant height } \\
(\mathrm{cm})\end{array}$ & $\begin{array}{l}\text { Shoot dry weight (g } \\
\text { per pot) }\end{array}$ & $\begin{array}{l}\text { Root dry weight (g } \\
\text { per pot) }\end{array}$ \\
\hline \multicolumn{4}{|l|}{ amendments } \\
\hline control & $31.79^{c}$ & $0.53^{c}$ & $0.06^{\mathrm{c}}$ \\
\hline biochar & $31.79^{c}$ & $0.68^{\mathrm{b}}$ & $0.07^{\mathrm{b}}$ \\
\hline manure & $35.26^{\mathrm{b}}$ & $0.79^{a}$ & $0.098^{\mathrm{a}}$ \\
\hline \multicolumn{4}{|l|}{ species } \\
\hline S. persica & $92.38^{\mathrm{a}}$ & $0.97^{\mathrm{a}}$ & $0.11^{\mathrm{a}}$ \\
\hline S. perspolitana & $36.60^{a}$ & $36.0^{b}$ & $0.039^{b}$ \\
\hline \multicolumn{4}{|c|}{$\begin{array}{l}\text { Different concentrations } \\
\text { of } \mathrm{Cr}\end{array}$} \\
\hline $\mathrm{Cr}_{0}$ & $34.39^{b}$ & $1.12^{\mathrm{a}}$ & $0.17^{\mathrm{a}}$ \\
\hline $\mathrm{Cr}_{5}$ & $45.33^{\mathrm{a}}$ & $0.81^{\mathrm{b}}$ & $0.067^{\mathrm{b}}$ \\
\hline $\mathrm{Cr}_{10}$ & $37.28^{b}$ & $0.45^{\mathrm{c}}$ & $0.046^{\mathrm{c}}$ \\
\hline $\mathrm{Cr}_{15}$ & $32.36^{c}$ & $0.29^{d}$ & $0.02^{\mathrm{d}}$ \\
\hline
\end{tabular}

227 Different letters indicate statistically significant differences at $\mathrm{P}>0.05$.

3.5 The effect of different concentrations of hexavalent chromium, manure, and biochar on the root and shoot dry weight of S. persica and S. perspolitana

Table 3 shows the results of the mean comparison of the interaction effects of different concentrations of chromium, manure, and biochar on the root and shoot dry weight of S. persica and S. perspolitana. According to these results, different concentrations of chromium negatively

233 influenced on the dry shoot weight of the two studied species. Concentrations of chromium as 5, 23410 , and $15 \mathrm{mg} / \mathrm{kg}$ resulted in decreased shoot dry weight of S. persica species by $52.59 \%$, $66.88 \%$, and $88.31 \%$, while the decreases reported for S. perspolitana species were found to be

$23617.07 \%, 36.58 \%$, and 48.78\%, respectively, compared with controls.

237 According to the results, the organic compounds (manure and biochar) applied in this study 238 showed a positive effect on the dry shoot weight of the two studied species. When applying 239 biochar treatment at concentrations of 5,10 , and $15 \mathrm{mg} / \mathrm{kg}$ chromium, shoot dry weight 240 increased by $84.9 \%, 9.80 \%$ and $111.1 \%$, in S. persica species, and by $82.8 \%, 7.69 \%$ and $19.04 \%$ 
241 in S. perspolitana species compared to the control (without amendment), respectively. The

242 increases in shoot dry weight for the manure treatment at concentrations of and 5, 10 and 15

$243 \mathrm{mg} / \mathrm{kg}$ chromium were $115.06 \%, 49.01 \%$, and $100 \%$ for $\mathrm{S}$. persica species and $50 \%, 26.9 \%$,

244 and $76.1 \%$ for $S$. perspolitana compared to the controls, respectively.

245 The results concerning the mean comparison of the interaction effects of different concentrations

246 of chromium, manure , and biochar on the root dry weight of S. persica and S. perspolitana in

247 Table 3 indicated the negative effect of different concentrations of chromium on the root dry

248 weight of the two studied species, so that root dry weight decreased with increasing the

249 concentration of this element in the soil. The decreases reported at concentrations of 5, 10, and

$25015 \mathrm{mg} / \mathrm{kg}$ chromium were $69.23 \%, 89.61 \%$, and $94.61 \%$ for $S$. persica, and $30 \%, 63.6 \%$, and

$25163.4 \%$ for $S$. perspolitana species compared to the controls, respectively. Again, the organic

252 compounds used in this study, including manure and biochar, positively influenced on the root

253 dry weight of the two species. By applying of biochar into the soil at chromium concentrations of

2545,10 , and $15 \mathrm{mg} / \mathrm{kg}$, the root dry weight increased by $8.75 \%, 137.0 \%$, and $28.5 \%$ in S. persica

255 and $8.5 \%, 26.37 \%$, and $1.09 \%$ in S. perspolitana compared to the controls (without

256 amendment), respectively. The increases for the manure treatment at chromium concentrations of

2575,10 , and $15 \mathrm{mg} / \mathrm{kg}$ were $50 \%, 200 \%$, and $321.4 \%$ for $S$. persica and $8.5 \%, 251.6 \%$, and

$258156.8 \%$ in S. perspolitana, compared to the controls, respectively. For biochar treatment at

259 chromium concentrations of 5,10 , and $15 \mathrm{mg} / \mathrm{kg}$, the root dry weight decreased by $8.75 \%$,

$260137.0 \%$, and $28.5 \%$ in S. persica and by $8.5 \%, 26.37 \%$, and $1.09 \%$ in S. perspolitana compared

261 to the controls (without amendment), respectively.

262 Table 3. Mean comparison of the interaction effects of different concentrations of chromium,

263 manure and biochar on shoot and root dry weight in S. persica and S. perspolitana 


\begin{tabular}{|c|c|c|c|c|}
\hline $\begin{array}{l}\text { different concentrations } \\
\text { of chromium }\end{array}$ & Species & amendments & $\begin{array}{llll}\begin{array}{l}\text { Shoot } \\
\text { weight } \\
\text { pot })\end{array} & & \text { (g } & \text { dry } \\
\text { per }\end{array}$ & $\begin{array}{llll}\text { Root } & & \text { dry } \\
\text { weight } & \text { (g } & \text { per } \\
\text { pot }) & & \\
\end{array}$ \\
\hline \multirow[t]{6}{*}{$\mathrm{Cr}_{0}$} & \multirow[t]{3}{*}{ S. persica } & control & $1.54^{\mathrm{c}}$ & $0.26^{\mathrm{b}}$ \\
\hline & & biochar & $1.82^{\mathrm{ab}}$ & $0.27^{\mathrm{b}}$ \\
\hline & & manure & $1.93^{\mathrm{a}}$ & $0.3^{\mathrm{a}}$ \\
\hline & \multirow[t]{3}{*}{ S.perspolitana } & control & $0.41^{\text {fghi }}$ & $0.05^{\text {efgh }}$ \\
\hline & & biochar & $0.49^{\text {efgh }}$ & $0.06^{\text {defg }}$ \\
\hline & & manure & $0.52^{\text {defg }}$ & $0.062^{\text {defg }}$ \\
\hline \multirow[t]{6}{*}{$\mathrm{Cr}_{5}$} & \multirow[t]{3}{*}{ S. persica } & control & $0.73^{\mathrm{de}}$ & $0.08^{\mathrm{de}}$ \\
\hline & & biochar & $1.35^{\mathrm{c}}$ & $0.087^{\mathrm{d}}$ \\
\hline & & manure & $1.57 \mathrm{bc}$ & $0.12_{\mathrm{c}}$ \\
\hline & \multirow[t]{3}{*}{ S.perspolitana } & control & 0.34 fghi & 0.035 fghi \\
\hline & & biochar & 0.37 fghi & 0.038 fghi \\
\hline & & manure & 0.51 defg & 0.038 fghi \\
\hline \multirow[t]{6}{*}{$\mathrm{Cr}_{10}$} & \multirow[t]{3}{*}{ S. persica } & control & 0.51 fghi & $0.027 \mathrm{ghi}$ \\
\hline & & biochar & 0.56 def & $0.064 \mathrm{def}$ \\
\hline & & manure & $0.76 \mathrm{~d}$ & $0.081 \mathrm{de}$ \\
\hline & \multirow[t]{3}{*}{ S.perspolitana } & control & 0.26 ghi & $0.0182^{\mathrm{hi}}$ \\
\hline & & biochar & 0.28 ghi & $0.023 \mathrm{hi}$ \\
\hline & & manure & 0.33 fghi & 0.064 def \\
\hline \multirow[t]{6}{*}{$\mathrm{Cr}_{15}$} & \multirow[t]{3}{*}{ S. persica } & control & $0.18 \mathrm{i}$ & $0.0183 \mathrm{hi}$ \\
\hline & & biochar & 0.38 fghi & $0.0185 \mathrm{hi}$ \\
\hline & & manure & $0.36^{\text {fghi }}$ & $0.047^{\text {efghi }}$ \\
\hline & \multirow[t]{3}{*}{ S.perspolitana } & control & $0.21^{\mathrm{i}}$ & $0.014^{\mathrm{i}}$ \\
\hline & & biochar & $0.25^{\text {hi }}$ & $0.018^{\text {hi }}$ \\
\hline & & manure & $0.37^{\text {fghi }}$ & $0.059^{\text {defg }}$ \\
\hline
\end{tabular}

3.6 Effect of different concentrations of chromium, manure, and biochar on chlorophyll a and

267 The results of the mean comparison of the interaction effects of different concentrations of

268 chromium, manure, and biochar on the content of photosynthetic pigments in S. persica and $S$.

269 perspolitana are shown in Tables 4. According to these results, different concentrations of 270 chromium negatively influenced on the content of chlorophyll $a$ and $b$ in the two studied species

271 so that the content of chlorophyll $\mathrm{a}$ and $\mathrm{b}$ decreased with increasing chromium in the soil. At 272 chromium concentration of 5,10 and $15 \mathrm{mg} / \mathrm{kg}$ in $S$. persica, the reported decreases were 
$27331.37 \%, 28.23 \%$ and $27.45 \%$ for chlorophyll $a$ and $39.54 \%, 38.04 \%$ and $35.03 \%$ for chlorophyll

$274 b$, respectively. In S. perspolitana, the contents of chlorophyll decreased by $28.01 \%, 28.8 \%$, and

$27539.22 \%$, and of chlorophyll $b$ by $15.6 \%, 18.7 \%$ and $27.6 \%$ compared to controls, respectively.

276 Applying of hexavalent chromium caused a significant reduction in chlorophyll contents. There

277 was a significant difference between different levels of chromium concentrations as 5, 10 , and

$27815 \mathrm{mg} / \mathrm{kg}$ in terms of decreases in chlorophyll $a$ and $b$ (Table 4). The organic compounds

279 (manure and biochar) used in this study also indicated a positive effect on the content of

280 photosynthetic pigments in the two studied species. By applying the biochar treatment on $S$.

281 persica species at chromium concentrations of 5,10 , and $15 \mathrm{mg} / \mathrm{kg}$, chlorophyll content

282 increased by $49.71 \%, 19.6 \%$, and $11.35 \%$ and the values for chlorophyll $b$ by $61.4 \%, 25.4 \%$,

283 and $0.3 \%$. For $S$. perspolitana, applying of biochar resulted in increases in chlorophyll $a$ by

$28429.9 \%, 35.75$, and $52.48 \%$ and in chlorophyll $b$ by $26.85 \%, 36.52 \%$, and $40.66 \%$ compared to

285 the controls (without amendment), respectively. Also, in the manure treatment at chromium

286 concentrations of 5,10 , and $15 \mathrm{mg} / \mathrm{kg}$, the content of chlorophyll $a$ decreased by $3.4 \%, 5.4 \%$

287 and $6.4 \%$, and of chlorophyll $b$ by $10.74 \%, 10.19 \%$, and $15.3 \%$ in $S$. persica species,

288 respectively. For S. perspolitana species, the decreases in chlorophyll $a$ were as $29.3 \%, 24.24 \%$,

289 and $47.5 \%$, and in chlorophyll $b$ as $24.21 \%, 9.6 \%$, and $29.9 \%$, respectively, compared to the

290 control (without amendment). In general, the highest content of chlorophyll $a(2.73 \mathrm{mg} / \mathrm{g}$ fresh

291 weight) was found in $S$. persica species at chromium concentration of $0 \mathrm{mg} / \mathrm{kg}$ in biochar

292 treatment, and the lowest content (1.41 $\mathrm{mg} / \mathrm{g}$ fresh weight) was found for $S$. perspolitana species

293 at chromium concentration of $15 \mathrm{mg} / \mathrm{kg}$ in the control treatment (without amendment). Also, the

294 highest content of chlorophyll $b(0.669 \mathrm{mg} / \mathrm{g}$ fresh weight) was found in $S$. persica species at 295 chromium concentration of $0 \mathrm{mg} / \mathrm{kg}$ in Biochar treatment, and the lowest content $(0.36 \mathrm{mg} / \mathrm{g}$ 
fresh weight) has belonged to $S$. perspolitana species at chromium concentration of $15 \mathrm{mg} / \mathrm{kg}$ in

297 the control treatment (without amendment)

298 Table 4. Mean comparison of the interaction effects of different concentrations of chromium,

299 manure and biochar on the content of photosynthetic pigments in S. persica and S. perspolitana

\begin{tabular}{|c|c|c|c|c|c|}
\hline $\begin{array}{l}\text { different } \\
\text { concentrations } \\
\text { of chromium }\end{array}$ & Species & amendments & $\begin{array}{l}\text { Chlorophyll } \\
a \text { (mg. fresh } \\
\text { weight) }\end{array}$ & $\begin{array}{l}\text { Chlorophyll } \\
b \text { (mg. fresh } \\
\text { weight) }\end{array}$ & $\begin{array}{l}\text { Carotenoid } \\
\text { (mg. fresh } \\
\text { weight) }\end{array}$ \\
\hline \multirow[t]{6}{*}{$\mathrm{Cr}_{0}$} & \multirow[t]{3}{*}{ S. persica } & control & $2.55^{b c}$ & $0.665^{\mathrm{a}}$ & $160.5^{c}$ \\
\hline & & biochar & $2.73^{a}$ & $0.669^{a}$ & $160.5^{c}$ \\
\hline & & manure & $2.63^{a b}$ & $0.661^{a}$ & $160.1^{\mathrm{c}}$ \\
\hline & \multirow[t]{3}{*}{ S.perspolitana } & control & $2.32^{\text {ef }}$ & $0.4989^{h}$ & $147.4^{\mathrm{k}}$ \\
\hline & & biochar & $2.47^{\mathrm{cd}}$ & $0.5100^{\mathrm{fg}}$ & $163.3^{b}$ \\
\hline & & manure & $2.42^{\mathrm{de}}$ & $0.5043^{\text {gh }}$ & $156.1^{\mathrm{d}}$ \\
\hline \multirow[t]{6}{*}{$\mathrm{Cr}_{5}$} & \multirow[t]{3}{*}{ S. persica } & control & $1.75^{\mathrm{mn}}$ & $0.402^{\circ}$ & $115.3^{\mathrm{s}}$ \\
\hline & & biochar & $2.62^{b}$ & $0.649^{b}$ & $167.2^{a}$ \\
\hline & & manure & $1.81^{\mathrm{m}}$ & $0.4471^{\mathrm{jk}}$ & $124.9^{\circ}$ \\
\hline & \multirow[t]{3}{*}{ S.perspolitana } & control & $1.67^{n}$ & $0.4208^{\mathrm{m}}$ & $131.3^{\circ}$ \\
\hline & & biochar & $2.17^{\text {gh }}$ & $0.5338^{d}$ & $149.2^{\mathrm{e}}$ \\
\hline & & manure & $2.16^{\text {ghi }}$ & $0.5227^{\mathrm{e}}$ & $148.4^{\mathrm{f}}$ \\
\hline \multirow[t]{6}{*}{$\mathbf{C r}_{10}$} & \multirow[t]{3}{*}{ S. persica } & control & $1.83^{\mathrm{lm}}$ & $0.412^{\mathrm{mn}}$ & $119.7^{q}$ \\
\hline & & biochar & $2.19^{g}$ & 0.517 ef & $137.9^{\mathrm{i}}$ \\
\hline & & manure & $1.93^{\mathrm{kl}}$ & $0.454^{j}$ & $128.6^{\mathrm{m}}$ \\
\hline & \multirow[t]{3}{*}{ S.perspolitana } & control & $1.65^{n}$ & $0.4052^{\text {no }}$ & $122.1^{\mathrm{p}}$ \\
\hline & & biochar & $2.24 \mathrm{fg}$ & $0.5532^{\mathrm{c}}$ & $163.6^{b}$ \\
\hline & & manure & $2.05^{\mathrm{ij}}$ & $0.4442^{\mathrm{k}}$ & $134.3^{j}$ \\
\hline \multirow[t]{6}{*}{$\mathrm{Cr}_{15}$} & \multirow[t]{3}{*}{ S. persica } & control & $1.85^{\mathrm{lm}}$ & $0.432^{1}$ & $125.2^{\circ}$ \\
\hline & & biochar & $2.06^{\text {hij }}$ & $0.445^{\mathrm{k}}$ & $129^{\mathrm{lm}}$ \\
\hline & & manure & $1.97^{\mathrm{jk}}$ & $0.4983^{h}$ & $126.3^{n}$ \\
\hline & \multirow[t]{3}{*}{ S.perspolitana } & control & $1.41^{\circ}$ & $0.361^{\mathrm{p}}$ & $118.4^{\mathrm{r}}$ \\
\hline & & biochar & $2.15^{\text {ghi }}$ & $0.5078^{\mathrm{g}}$ & $144.3^{h}$ \\
\hline & & manure & $2.08^{\text {hig }}$ & $0.4691^{\mathrm{i}}$ & $129^{1}$ \\
\hline
\end{tabular}

different letters indicate statistically significant differences at $\mathrm{P}>0.05$.

3.7 Effect of different concentrations of hexavalent chromium, manure, and biochar on carotenoid content in S. persica and S. perspolitana

303 Table 4 shows the results of the mean comparison of the interaction effects of different concentrations of chromium, manure, and biochar on the carotenoid content of $S$.persica and $S$. 
perspolitana. According to these results, the different concentrations of chromium negatively influenced on the carotenoid content in the two species so that the carotenoid content decreased with increasing the concentration of this heavy metal in the soil. At three chromium concentrations of 5,10 , and $15 \mathrm{mg} / \mathrm{kg}$, the carotenoid content decreased by $28.16 \%, 25.42 \%$, and $21.99 \%$ in S. persica, and by $10.92 \%, 17.16 \%$, and $19.67 \%$ in S. perspolitana compared to the controls, respectively. Thus, the organic compounds used in this study indicated a positive effect on the carotenoid content of the two species. In biochar treatment at chromium concentrations of 5,10 , and $15 \mathrm{mg} / \mathrm{kg}$, the carotenoid content in $S$. persica increased by $45.01 \%, 15.20 \%$, and $3.03 \%$ and in S. perspolitana by $13.6 \%, 33.9 \%$, and $21.8 \%$ compared to the controls, respectively. Also, in manure treatment at chromium concentrations of 5, 10 , and $15 \mathrm{mg} / \mathrm{kg}$, the increases in carotenoid content were $8.32 \%, 7.43 \%$, and $0.87 \%$ in $S$. persica, and $13.02 \%, 9.99 \%$, and $8.95 \%$ in S. perspolitana compared to the controls, respectively.

\subsection{The effect of different concentrations of chromium, manure, and biochar on the total} phenolic content in S. persica and S. perspolitana

Table 5 shows the results of the mean comparison of the interaction effects of different concentrations of chromium, manure, and biochar on the total phenolic content in S. persica and S. perspolitana. According to these results, different concentrations of chromium negatively affected on the total phenolic content of the two studied species, and so that the total phenolic content in the plant decreased with increasing the concentration of chromium in the soil. At three chromium concentrations of 5,10 , and $15 \mathrm{mg} / \mathrm{kg}$, the total phenolic content in $S$. persica species decreased by $39.30 \%, 39.86 \%$, and $49.73 \%$, and in S. perspolitana by $34.75 \%, 42.44 \%$, and $60.35 \%$ compared to the controls, respectively. Again, the organic compounds used in this study showed a positive effect on the total phenolic content of the two species. In biochar 
328 treatment at chromium concentrations of 5,10 , and $15 \mathrm{mg} / \mathrm{kg}$, the total phenolic content 329 increased by $62.95 \%, 67.30 \%$, and $111.16 \%$ in S. persica species, and by $24.26 \%, 11.31 \%$, and $33036.40 \%$ in $S$. perspolitana compared to the controls, respectively. Also, in manure treatment at 331 concentrations of 5,10 , and $15 \mathrm{mg} / \mathrm{kg}$, the increases in total phenolic content were $39.14 \%$, $33232.87 \%$, and $21.22 \%$ for S. persica, and $3.54 \%, 5.26 \%$, and $22.35 \%$ for S. perspolitana 333 compared to the controls, respectively.

334 Table 5. Mean comparison of the interaction effects of different concentrations of chromium, 335 manure and biochar on the total phenolic content in S. persica and S. perspolitana.

\begin{tabular}{|c|c|c|c|}
\hline $\begin{array}{l}\text { different concentrations } \\
\text { of chromium }\end{array}$ & Species & amendments & $\begin{array}{l}\text { total phenolic content (mg gallic } \\
\text { acid per g fresh weight) }\end{array}$ \\
\hline \multirow[t]{6}{*}{$\mathrm{Cr}_{0}$} & \multirow[t]{3}{*}{ S. persica } & control & $37.58^{\text {bc }}$ \\
\hline & & biochar & $44.15^{\mathrm{a}}$ \\
\hline & & manure & $38.57^{b}$ \\
\hline & \multirow[t]{3}{*}{ S.perspolitana } & control & $30.7^{\mathrm{de}}$ \\
\hline & & biochar & $34.39^{\mathrm{cd}}$ \\
\hline & & manure & $34.13^{\mathrm{cd}}$ \\
\hline \multirow[t]{6}{*}{$\mathrm{Cr}_{5}$} & \multirow{3}{*}{ S. persica } & control & $22.81^{\mathrm{fg}}$ \\
\hline & & biochar & $37.17^{\mathrm{bc}}$ \\
\hline & & manure & $31.74^{\mathrm{de}}$ \\
\hline & \multirow[t]{3}{*}{ S.perspolitana } & control & 20.03 ghij \\
\hline & & biochar & $24.89^{\mathrm{f}}$ \\
\hline & & manure & $20.74^{\text {ghi }}$ \\
\hline \multirow[t]{6}{*}{$\mathrm{Cr}_{10}$} & \multirow[t]{3}{*}{ S. persica } & control & $22.6^{\text {fgh }}$ \\
\hline & & biochar & $37.81^{\mathrm{bc}}$ \\
\hline & & manure & $30.03^{\mathrm{e}}$ \\
\hline & \multirow[t]{3}{*}{ S.perspolitana } & control & $17.67 \mathrm{ijk}$ \\
\hline & & biochar & $19.67^{\text {ghij }}$ \\
\hline & & manure & $18.6^{\text {hijk }}$ \\
\hline \multirow[t]{6}{*}{$\mathrm{Cr}_{15}$} & \multirow[t]{3}{*}{ S. persica } & control & $81.89^{\text {ghijk }}$ \\
\hline & & biochar & $39.89^{b}$ \\
\hline & & manure & $22.9^{\mathrm{fg}}$ \\
\hline & \multirow[t]{3}{*}{ S.perspolitana } & control & $12.17^{1}$ \\
\hline & & biochar & $61.60^{\mathrm{jk}}$ \\
\hline & & manure & $14.89^{\mathrm{kl}}$ \\
\hline
\end{tabular}




\subsection{The effect of different concentrations of chromium, manure, and biochar on the values of}

accumulated chromium in roots and shoots of $S$. persica and $S$. perspolitana

Table 6 shows the mean comparison of the interaction effects of different concentrations of chromium, manure, and biochar on the accumulation of total chromium, $\mathrm{Cr}$ (VI), and $\mathrm{Cr}$ (III) in the roots of S.persica and S.perspolitana after six months of growing in the contaminated soil. Generally, the accumulation of chromium in the roots of both species was significantly affected by the chromium content in the soil so that the accumulation of chromium in the roots of both species increased by increasing the chromium concentration from 0 to $15 \mathrm{mg} / \mathrm{kg}$ in the soil. In $S$. persica, at chromium concentration of $0 \mathrm{mg} / \mathrm{kg}$, accumulation of total, hexavalent , and trivalent chromium in the roots of plants grown in contaminated soil (without amendment) were 17.77, 5.38 , and $16.86 \mathrm{mg} / \mathrm{kg}$. At chromium concentration of $15 \mathrm{mg} / \mathrm{kg}$, the corresponding values for accumulation of total, hexavalent, and trivalent chromium were $357.61,6.41$, and $351.19 \mathrm{mg} / \mathrm{kg}$

for this species. In $S$. perspolitana, at chromium concentration of $0 \mathrm{mg} / \mathrm{kg}$, accumulation of total, hexavalent, and trivalent chromium in the roots of plants grown in contaminated soil (without amendment) were $21.58,7.73$, and $13.85 \mathrm{mg} / \mathrm{kg}$. At chromium concentration of $15 \mathrm{mg} / \mathrm{kg}$, the values for accumulation of total, hexavalent, and trivalent chromium were 624.91, 46.08, and $578.83 \mathrm{mg} / \mathrm{kg}$ for this species. In total, the accumulation of total, hexavalent and trivalent chromium in the roots of $S$. perspolitana was higher than $S$. persica. The organic compounds used in this study showed a negative effect on the accumulation of total, hexavalent and trivalent chromium in the roots of the two studied species. In biochar treatment, the accumulation of total, hexavalent and trivalent chromium in S.persica species decreased by $33.89 \%, 50.39 \%$ and $33.60 \%$ at chromium concentration of $5 \mathrm{mg} / \mathrm{kg}, 76.47 \%, 73.09 \%$ and $76.5 \%$ at chromium concentration of $10 \mathrm{mg} / \mathrm{kg}$ and $25.01 \%, 81.7 \%$ and $23.39 \%$ at chromium concentration of 15 
$\mathrm{mg} / \mathrm{kg}$. In S. perspolitana species under biochar treatment, the accumulation of total, hexavalent and trivalent chromium decreased by $53.60 \%, 19.96 \%$ and $54.4 \%$ at chromium concentration of $5 \mathrm{mg} / \mathrm{kg}, 23.72 \%, 14.54 \%$ and $24.0 \%$ at chromium concentration of $10 \mathrm{mg} / \mathrm{kg}$ and $11.39 \%$, $32.53 \%$ and $9.50 \%$ at chromium concentration of $15 \mathrm{mg} / \mathrm{kg}$. In the manure treatment, the accumulation of total, hexavalent and trivalent chromium in S.persica species decreased by $23.82 \%, 36.24 \%$ and $23.61 \%$ at chromium concentration of $5 \mathrm{mg} / \mathrm{kg}, 22.73 \%, 51.85 \%$ and $22.13 \%$ at chromium concentration of $10 \mathrm{mg} / \mathrm{kg}$ and $1.75 \%, 52.32 \%$ and $0.22 \%$ at chromium concentration of $15 \mathrm{mg} / \mathrm{kg}$. In $\mathrm{S}$. perspolitana species under biochar treatment, the accumulation of total, hexavalent and trivalent chromium decreased by $26.36 \%, 8.11 \%$ and $22.96 \%$ at chromium concentration of $5 \mathrm{mg} / \mathrm{kg}, 21.55 \%, 2.02 \%$ and $22.22 \%$ at chromium concentration of $10 \mathrm{mg} / \mathrm{kg}$ and $9.48 \%, 16.96 \%$ and $8.81 \%$ at chromium concentration of $15 \mathrm{mg} / \mathrm{kg}$.

Table 6. Mean comparison of the interaction effects of different concentrations of chromium, manure and biochar on chromium accumulation in the roots of S. persica and S. perspolitana

\begin{tabular}{|c|c|c|c|c|c|}
\hline $\begin{array}{l}\text { different } \\
\text { concentrations } \\
\text { of chromium }\end{array}$ & Species & amendments & $\begin{array}{l}\text { Hexavalent } \\
\text { chromium } \\
\text { (mg.kg) }\end{array}$ & $\begin{array}{l}\text { Total } \\
\text { chromium } \\
\text { (mg.kg) }\end{array}$ & $\begin{array}{l}\text { Trivalent } \\
\text { chromium } \\
\text { (mg.kg) } \\
\end{array}$ \\
\hline \multirow[t]{6}{*}{$\mathrm{Cr}_{0}$} & \multirow[t]{3}{*}{ S. persica } & control & $1.05^{\mathrm{p}}$ & $20.39^{n}$ & $19.34^{\circ}$ \\
\hline & & biochar & $0.8^{p}$ & $16.27^{\mathrm{n}}$ & $15.47^{\circ}$ \\
\hline & & manure & $0.85^{\mathrm{p}}$ & $16.63^{n}$ & $15.78^{\circ}$ \\
\hline & \multirow[t]{3}{*}{ S.perspolitana } & control & $9.39^{j}$ & $24.54^{n}$ & $15.14^{\circ}$ \\
\hline & & biochar & $6^{1}$ & $19.4^{n}$ & $13.4^{\circ}$ \\
\hline & & manure & $7.8^{\mathrm{k}}$ & $20.8^{n}$ & $13^{\circ}$ \\
\hline \multirow[t]{6}{*}{$\mathrm{Cr}_{5}$} & \multirow[t]{3}{*}{ S. persica } & control & $7.56^{\mathrm{k}}$ & $440.99 \mathrm{fg}$ & $433.42^{\mathrm{fg}}$ \\
\hline & & biochar & $3.75^{n}$ & $291.53^{k}$ & $287.78^{1}$ \\
\hline & & manure & $4.82^{\mathrm{m}}$ & $335.91^{\mathrm{j}}$ & $331.08^{\mathrm{k}}$ \\
\hline & \multirow[t]{3}{*}{ S.perspolitana } & control & $15.03^{\mathrm{f}}$ & $589.67^{c}$ & $574.63^{b}$ \\
\hline & & biochar & $12.03^{\mathrm{h}}$ & $273.59^{1}$ & $261.53^{\mathrm{m}}$ \\
\hline & & manure & $13.81^{\mathrm{g}}$ & $434.18^{\mathrm{g}}$ & $420.36^{\mathrm{h}}$ \\
\hline \multirow[t]{5}{*}{$\mathrm{Cr}_{10}$} & \multirow[t]{3}{*}{ S. persica } & control & $10.78^{i}$ & $532.27^{d}$ & $521.48^{\mathrm{e}}$ \\
\hline & & biochar & $9.2^{\text {no }}$ & $125.21^{\mathrm{m}}$ & $122.31^{\mathrm{n}}$ \\
\hline & & manure & $5.19^{\mathrm{lm}}$ & $411.27^{\mathrm{h}}$ & $406.07^{\mathrm{i}}$ \\
\hline & \multirow[t]{2}{*}{ S.perspolitana } & control & $19.8^{\mathrm{d}}$ & $588.99^{c}$ & $569.19^{b c}$ \\
\hline & & biochar & $16.92^{\mathrm{e}}$ & $449.27^{\mathrm{f}}$ & $432.34^{\mathrm{g}}$ \\
\hline
\end{tabular}




\begin{tabular}{|l|l|l|l|l|l|}
\hline & & manure & $19.4^{\mathrm{d}}$ & $462.06^{\mathrm{e}}$ & $442.66^{\mathrm{f}}$ \\
\hline \multirow{3}{*}{$\mathbf{C r}_{15}$} & \multirow{3}{*}{ S. persica } & control & $11.6^{\mathrm{hi}}$ & $392.81^{\mathrm{i}}$ & $381.21^{\mathrm{j}}$ \\
\cline { 3 - 6 } & biochar & $2.12^{\mathrm{o}}$ & $294.53^{\mathrm{k}}$ & $292.01^{\mathrm{l}}$ \\
\cline { 2 - 6 } & manure & $5.53^{\mathrm{lm}}$ & $385.9^{\mathrm{i}}$ & $380.36^{\mathrm{j}}$ \\
\cline { 2 - 6 } & \multirow{3}{*}{ S.perspolitana } & control & $55.18^{\mathrm{a}}$ & $671.66^{\mathrm{a}}$ & $616.48^{\mathrm{a}}$ \\
\cline { 3 - 6 } & biochar & $37.23^{\mathrm{c}}$ & $595.13^{\mathrm{c}}$ & $557.89^{\mathrm{d}}$ \\
\cline { 3 - 6 } & manure & $45.82^{\mathrm{b}}$ & $607.94^{\mathrm{b}}$ & $562.11^{\mathrm{cd}}$ \\
\hline
\end{tabular}

373

374

375

376

377

378

379

380

381

382

383

384

385

386

387

388 389 for this species.

390 Unlike roots, accumulation of total, hexavalent, and trivalent chromium in shoots of S. persica

391

different letters indicate statistically significant differences at $\mathrm{P}>0.05$.

Table 7 indicates the mean comparison of the interaction effects of different concentrations of chromium, manure, and biochar on the accumulation of total, hexavalent, and trivalent chromium in the shoots of $S$. persica and S. perspolitana after six months of growing in the contaminated soil. Like the results obtained for the roots, the accumulation of chromium in the shoots of both species was significantly affected by the chromium content in the soil. In other words, chromium accumulation in the shoot showed an increasing trend with increasing chromium concentration from 0 to $15 \mathrm{mg} / \mathrm{kg}$ in the soil for both species. In $S$. persica, at chromium concentration of $0 \mathrm{mg} / \mathrm{kg}$, accumulation of total, hexavalent, and trivalent chromium in the shoots of plants grown in contaminated soil (without amendment) were 2.07, 0.56, and $1.51 \mathrm{mg} / \mathrm{kg}$. At chromium concentration of $15 \mathrm{mg} / \mathrm{kg}$, the corresponding values for accumulation of total, hexavalent, and trivalent chromium were $33.54,1.12$, and $32.42 \mathrm{mg} / \mathrm{kg}$ for this species. In $S$. perspolitana, at chromium concentration of $0 \mathrm{mg} / \mathrm{kg}$, accumulation of total, hexavalent , and trivalent chromium in the shoots of plants grown in contaminated soil (without amendment) were $1.03,0.33$, and $0.7 \mathrm{mg} / \mathrm{kg}$. At chromium concentration of $15 \mathrm{mg} / \mathrm{kg}$, the values for accumulation of total, hexavalent, and trivalent chromium were $28.41,1.25$, and $27.16 \mathrm{mg} / \mathrm{kg}$ was higher than $S$. perspolitana. As shown in table 7, the organic compounds used in this study 
392 hurt the accumulation of total, hexavalent, and trivalent chromium in the shoots of the two 393 species.

394 In biochar treatment, the accumulation of total, hexavalent and trivalent chromium in S.persica 395 species decreased by $91.83 \%, 39.66 \%$ and $93.61 \%$ at chromium concentration of $5 \mathrm{mg} / \mathrm{kg}$, $93.22 \%, 72.53 \%$ and $93.78 \%$ at chromium concentration of $10 \mathrm{mg} / \mathrm{kg}$ and $93.60 \%, 24.42 \%$ and

$39794.66 \%$ at chromium concentration of $15 \mathrm{mg} / \mathrm{kg}$. In $S$. perspolitana species under biochar 398 treatment, the accumulation of total, hexavalent and trivalent chromium decreased by $73.06 \%$, $29.68 \%$ and $75.07 \%$ at chromium concentration of $5 \mathrm{mg} / \mathrm{kg}, 60.05 \%, 26.08 \%$ and $61.29 \%$ at 400 chromium concentration of $10 \mathrm{mg} / \mathrm{kg}$ and $70.96 \%, 61.11 \%$ and $71.36 \%$ at chromium

401 402 403 404 405 406 407 408 409 410 concentration of $15 \mathrm{mg} / \mathrm{kg}$. In the manure treatment, the accumulation of total, hexavalent and trivalent chromium in S.persica species decreased by $51.53 \%, 14.04 \%$ and $52.77 \%$ at chromium concentration of $5 \mathrm{mg} / \mathrm{kg}, 88.50 \%, 55.44 \%$ and $89.40 \%$ at chromium concentration of $10 \mathrm{mg} / \mathrm{kg}$ and $90.62 \%, 19.08 \%$ and $91.71 \%$ at chromium concentration of $15 \mathrm{mg} / \mathrm{kg}$. In S. perspolitana species under biochar treatment, the accumulation of total, hexavalent and trivalent chromium decreased by $48.89 \%, 21.87 \%$ and $50.14 \%$ at chromium concentration of $5 \mathrm{mg} / \mathrm{kg}, 33.23 \%$, $21.73 \%$ and $33.65 \%$ at chromium concentration of $10 \mathrm{mg} / \mathrm{kg}$ and $60.90 \%, 50 \%$ and $61.36 \%$ at chromium concentration of $15 \mathrm{mg} / \mathrm{kg}$.

Table 7. Mean comparison of the interaction effects of different concentrations of chromium, manure and biochar on chromium accumulation in shoots of S. persica and $S . p$

\begin{tabular}{|l|l|l|l|l|l|}
\hline $\begin{array}{l}\text { different } \\
\text { concentrations } \\
\text { of chromium }\end{array}$ & Species & amendments & $\begin{array}{l}\text { Hexavalent } \\
\text { chromium } \\
\text { (mg.kg) }\end{array}$ & $\begin{array}{l}\text { Total } \\
\text { chromium } \\
\text { (mg.kg) }\end{array}$ & $\begin{array}{l}\text { Trivalent } \\
\text { chromium } \\
\text { (mg.kg) }\end{array}$ \\
\hline \multirow{2}{*}{ Cro } & \multirow{2}{*}{ S. persica } & control & $0.65^{\text {fghi }}$ & $2.06^{\mathrm{lm}}$ & $1.41^{\mathrm{kl}}$ \\
\cline { 3 - 6 } & biochar & $0.5^{\text {hijk }}$ & $2.14^{\mathrm{lm}}$ & $1.64^{\mathrm{kl}}$ \\
\cline { 3 - 6 } & manure & $0.54^{\mathrm{ghij}}$ & $2.03^{\mathrm{lm}}$ & $1.49^{\mathrm{kl}}$ \\
\cline { 3 - 6 } & \multirow{2}{*}{ S.perspolitana } & control & $0.37^{\mathrm{jk}}$ & $1.05^{\mathrm{m}}$ & $0.68^{1}$ \\
\cline { 3 - 6 } & biochar & $0.28^{\mathrm{k}}$ & $0.99^{\mathrm{m}}$ & $0.7^{1}$ \\
\hline
\end{tabular}




\begin{tabular}{|c|c|c|c|c|c|}
\hline & & manure & $0.33^{\mathrm{jk}}$ & $1.04^{\mathrm{m}}$ & $0.71^{1}$ \\
\hline \multirow{6}{*}{$\mathrm{Cr}_{5}$} & \multirow[t]{3}{*}{ S. persica } & control & $1.21^{b c}$ & $37.24^{\mathrm{d}}$ & $36.02^{d}$ \\
\hline & & biochar & $0.73^{\text {fgh }}$ & $3.04^{\mathrm{kl}}$ & $2.3^{\mathrm{jk}}$ \\
\hline & & manure & $1.04^{\mathrm{cd}}$ & $18.05^{\mathrm{f}}$ & $17.01^{\mathrm{f}}$ \\
\hline & \multirow[t]{3}{*}{ S.perspolitana } & control & $0.64^{\text {fghi }}$ & $14.48^{\mathrm{g}}$ & $13.84^{\mathrm{g}}$ \\
\hline & & biochar & $0.45^{\mathrm{ijk}}$ & $3.9^{\mathrm{jk}}$ & $3.45^{\mathrm{ij}}$ \\
\hline & & manure & $0.5^{\text {hijk }}$ & $7.4^{h}$ & $6.9^{h}$ \\
\hline \multirow[t]{6}{*}{$\mathrm{Cr}_{10}$} & \multirow[t]{3}{*}{ S. persica } & control & $1.93^{\mathrm{a}}$ & $72.73^{b}$ & $70.8^{b}$ \\
\hline & & biochar & $0.53^{\text {ghij }}$ & $4.93^{\mathrm{ij}}$ & $4.4^{\mathrm{i}}$ \\
\hline & & manure & $0.86^{\text {def }}$ & $8.36^{h}$ & $7.5^{h}$ \\
\hline & \multirow[t]{3}{*}{ S.perspolitana } & control & $0.69^{\text {fgh }}$ & $20.13^{\mathrm{e}}$ & $19.43^{\mathrm{e}}$ \\
\hline & & biochar & $0.51^{\text {hijk }}$ & $8.04^{\mathrm{h}}$ & $7.52^{h}$ \\
\hline & & manure & $0.54^{\text {ghij }}$ & $13.44^{\mathrm{g}}$ & $12.89^{\mathrm{g}}$ \\
\hline \multirow{6}{*}{$\mathrm{Cr}_{15}$} & \multirow[t]{3}{*}{ S. persica } & control & $1.31^{\mathrm{b}}$ & $86.93^{\mathrm{a}}$ & $85.62^{\mathrm{a}}$ \\
\hline & & biochar & $0.99^{\text {cde }}$ & $5.56^{\mathrm{i}}$ & $4.57^{\mathrm{i}}$ \\
\hline & & manure & $1.06^{\mathrm{cd}}$ & $8.15^{h}$ & $7.09^{h}$ \\
\hline & \multirow[t]{3}{*}{ S.perspolitana } & control & $1.98^{\mathrm{a}}$ & $50.7^{\mathrm{c}}$ & $48.71^{c}$ \\
\hline & & biochar & $0.77^{\text {efg }}$ & $14.72^{\mathrm{g}}$ & $13.95^{\mathrm{g}}$ \\
\hline & & manure & $0.99^{\text {cde }}$ & $19.82^{\mathrm{e}}$ & $18.82^{\mathrm{e}}$ \\
\hline
\end{tabular}

different letters indicate statistically significant differences at $\mathrm{P}>0.05$.

3.10 Determination of $T F^{1}, B C F^{2}, B A C^{3}$ indices to evaluate the phytoremediation ability of $S$. persica and S. perspolitana species

414 In order to evaluate the phytoremediation potential of plants after determining the concentration 415 of heavy metals in plant and soil samples, it should be necessary to calculated indices including 416 TF (Translocation Factor; a ratio of metal concentrations in shoots to roots), BCF (Bio 417 Concentration Factor; ratio of metal concentrations in roots to soil), BAC (Biological 418 Accumulation Coefficient; the a ratio of metal concentration in shoots to soil) because the 419 phytoremediation potential of a species is calculated using these indices. The values of TF 420 greater than 1 indicate that the plant is suitable for extracting the contaminants. Also, plants with 421 values of TF and BAC greater than one are suitable for phytoremediation of the contaminants. 422 Plants with $\mathrm{TF}$ value lower than 1 and $\mathrm{BCF}$ values higher than one are suitable for 423 phytostabilization(Yoon et al. 2006). 
424 The results concerning the effect of the studied treatments on the accumulation of metals in 425 Table 8 showed that the value of TF for heavy metals was lower than 1 in all treatments.

426 Therefore, both $S$. persica and $S$. perspolitana would serve as suitable species for

427 phytostabilization.

428 Table 8. Mean values of TF, BCF and BAC related to total chromium in S. persica and $S$. 429 perspolitana.

\begin{tabular}{|c|c|c|c|c|c|}
\hline $\begin{array}{lll}\text { different } & \text { concentrations } & \text { of } \\
\text { chromium }\end{array}$ & Species & amendments & TF & BAC & BCF \\
\hline \multirow[t]{6}{*}{$\mathrm{Cr}_{0}$} & \multirow[t]{3}{*}{ S. persica } & control & 0.010 & 0.028 & 0.280 \\
\hline & & biochar & 0.13 & 0.029 & 0.223 \\
\hline & & manure & 0.12 & 0.027 & 0.228 \\
\hline & \multirow[t]{3}{*}{ S.perspolitana } & control & 0.043 & 0.014 & 0.33 \\
\hline & & biochar & 0.051 & 0.013 & 0.26 \\
\hline & & manure & 0.050 & 0.014 & 0.28 \\
\hline \multirow[t]{6}{*}{$\mathrm{Cr}_{5}$} & \multirow[t]{3}{*}{ S. persica } & control & 0.084 & 0.47 & 5.67 \\
\hline & & biochar & 0.010 & 0.039 & 3.75 \\
\hline & & manure & 0.053 & 0.915 & 4.32 \\
\hline & \multirow[t]{3}{*}{ S.perspolitana } & control & 0.02 & 0.18 & 7.59 \\
\hline & & biochar & 0.0142 & 0.050 & 3.52 \\
\hline & & manure & 0.017 & 0.095 & 5.59 \\
\hline \multirow[t]{6}{*}{$\mathrm{Cr}_{10}$} & \multirow[t]{3}{*}{ S. persica } & control & 0.13 & 0.87 & 6.43 \\
\hline & & biochar & 0.039 & 0.059 & 1.51 \\
\hline & & manure & 0.020 & 0.102 & 4.91 \\
\hline & \multirow[t]{3}{*}{ S.perspolitana } & control & 0.034 & 0.24 & 7.12 \\
\hline & & biochar & 0.017 & 0.097 & 5.43 \\
\hline & & manure & 0.029 & 0.16 & 5.58 \\
\hline \multirow[t]{6}{*}{$\mathrm{Cr}_{15}$} & \multirow[t]{3}{*}{ S. persica } & control & 0.22 & 0.99 & 4.480 \\
\hline & & biochar & 0.01 & 0.063 & 3.35 \\
\hline & & manure & 0.021 & 0.092 & 4.40 \\
\hline & \multirow[t]{3}{*}{ S.perspolitana } & control & 0.075 & 0.57 & 7.66 \\
\hline & & biochar & 0.024 & 0.167 & 6.78 \\
\hline & & manure & 0.032 & 0.22 & 6.93 \\
\hline
\end{tabular}

$\mathrm{Cr}_{0}$ : without chromium, $\mathrm{Cr}_{5}$ : chromium concentration of $5 \mathrm{mg} / \mathrm{kg}, \mathrm{Cr}_{10}$ : chromium concentration

431 of $10 \mathrm{mg} / \mathrm{kg}, \mathrm{Cr}_{15}$ : chromium concentration of $15 \mathrm{mg} / \mathrm{kg}$ 


\section{4. Discussion}

433 4.1 The effect of hexavalent chromium on germination traits of S. persica and S. perspolitana

434 Heavy elements are limiting factors in the germination and growth stages of the seedling.

435 Response to environmental stresses is a complex and undeniable phenomenon in higher

436 plants(Díaz et al. 2001). In this regard, both S. persica and S. perspolitana species showed a 437 similar response of reduced germination under increased chromium concentration. Seed 438 germination is dependent on protein activity, which decreased under chromium treatment. Both 439 Salicornia species indicated decreased growth with increasing hexavalent chromium 440 concentration, and it was also found that chromium negatively influenced on root and stem

441 length. Decreased growth in a plant may be due to reduced growth in the roots and consequently 442 deficient transfer of nutrients to the upper parts of the plant. Also, the transfer of chromium to 443 the plant shoot could directly affect its cellular metabolism, which leads to a decreased seedling 444 length(Shanker et al. 2005).

445 The study of the effect of heavy metals on plant characteristics seems to be necessary to identify 446 suitable plants for phytoremediation of contaminated soils on the one hand, and to identify 447 resistant plant genotypes on the other hand. Bhardwaj et al.(Bhardwaj et al. 2009). demonstrated 448 that the germination (\%) of bean plant was not affected at low cadmium concentrations than the 449 control, but prevented germination was observed at higher cadmium concentrations of $3 \mathrm{~g} / \mathrm{kg}$ 450 soil. Peralta et al. (Peralta et al. 2001). reported a decrease in seed germination, root, and shoot 451 length with increasing concentration of cadmium in soil under alfalfa plant (Medicago satival).

452 Seed germination was the same as the control at a cadmium concentration of $5 \mathrm{mg} / \mathrm{l}$, although the 453 stem length reduced by about $17 \%$ and the root length increased by about $22 \%$ compared to the 454 control treatment, but decreases in seed germination and seedling length was significant at a 
455 concentration of $10 \mathrm{mg} / \mathrm{l}$. Also, a cadmium concentration of $40 \mathrm{mg} / \mathrm{l}$ led to the death of most

456 alfalfa seedlings. Authors have reported delayed seedling emergence as a sign of cadmium

457 toxicity. Therefore, the results of the mentioned studies are consistent with the findings of this

458 investigation so that a decrease in the traits related to seed germination rate was observed with

459 increasing the concentration of heavy metals in both S. persica and S. perspolitana.

460 Heavy metals cause serious damage to the cell by inducing a lack of active oxygen production.

461 As vital stages in the plant life cycle, germination and establishment of seedlings can be affected

462 by high levels of heavy metals. Chromium toxicity at concentrations of 5, 25, 100 , and 150

$463 \mathrm{mg} / \mathrm{kg}$ had a significant effect on seedling growth. Chromium treatment at $100 \mathrm{mg} / \mathrm{kg}$ negatively

464 influenced on germination indices of okra (Hibiscus esculentus)(Amin et al. 2013).

465 Also, in a study, it was found that the Vigna radiata did not tolerate chromium concentrations

466 higher than $50 \mathrm{mg} / \mathrm{l}$ (Murtaza et al. 2018). In the present study, the results regarding the seedling

467 growth showed a similar trend, so that stem length also decreased with decreasing root length in

468 both $S$. persica and $S$. perspolitana species, which may be due to reduced nutrients. Therefore,

469 the present study confirmed that seed germination and seedling growth are affected by different

470 concentrations of chromium. Results with different concentrations of chromium in comparison

471 with the control treatment demonstrated a decrease in germination parameters for both S. persica

472 and $S$. perspolitana species confirming the findings obtained by other researchers.

4734.2 Effect of experimental treatments on plant physiological parameters (plant height, root

$474 \quad$ and shoot length)

475 This study showed that different concentrations of chromium in the soil negatively influenced on

476 growth indices in both species so that the plant height decreased with increasing the

477 concentration of chromium in the soil, which is consistent with the results of other researches. In 
478 the case of Eruca sativa species, the presence of hexavalent chromium at a concentration of 500 $479 \mathrm{mg} / \mathrm{kg}$ in the soil(Kamran et al. 2017). Caused a decrease in plant height. By studying a number 480 of 32 plants, Lukina et al.(Lukina et al. 2016) reported that the toxicity of hexavalent chromium $481(1000 \mathrm{mg} / \mathrm{kg})$ indicated an adverse effect on $94 \%$ of the studied species. Decreased growth and 482 shoot height in plants are due to reduced root growth and development under the presence of 483 chromium, which can result in the decreased transfer of water and nutrients to the aerial parts of 484 the plant. Also, increased chromium transport to the shoot can directly affect sensitive plant 485 tissues (leaf), photosynthesis, and cellular metabolism of the shoot, thereby reducing plant 486 height. The effect of soil chromium on plant growth and yield appears in various forms , 487 including decreased water and nutrient uptake, impaired cell division, imbalance in critical 488 nutrient uptake and transport, plant inefficiency in selective uptake of inorganic nutrients, 489 increased production of free radicals, and oxidative damage to sensitive plant tissues such as 490 mitochondria, pigment content, RNA, DNA, lipids, etc.(Shahid et al. 2017).

491 All of these factors, individually or in combination, can influence on plant growth and 492 development as well as plant functioning at cellular and molecular levels.

493 The negative effect of chromium on root dry weight as a result of damage to root cells has also 494 been reported. Sundaramoorthy et al.(Sundaramoorthy et al. 2010).

495 found that chromium concentrations higher than 20 and $40 \mathrm{mg} / \mathrm{l}$ led to an inhibitory effect on 496 plant growth. Hexavalent chromium at a concentration of $200 \mathrm{mg} / \mathrm{l}$ also resulted in reduced root 497 growth in Asian rice (Oriza sativa $\mathrm{L}$ ). In another study, the roots of Zea maize under hexavalent 498 chromium treatment were characterized by shorter roots, lower dry weight, and brown color 499 (Bhalerao \&Sharma 2015). In the present study, different concentrations of chromium caused a 
500 decrease in the dry weight of the roots in both studied species, confirming the results of other 501 studies.

502 Our results also showed that the applied amendments had a positive effect on the growth indices 503 for both studied species. addition, addition of organic matter to the culture medium serves as one 504 of the factors improving soil conditions for plant growth. Organic matter can increase soil 505 aeration and improve soil physical structure and cation exchange capacity, which varies 506 depending on the type of organic matter (Moameri et al. 2017).

507 Atiyeh and Lee (2002) in an experiment investigated the effect of organic fertilizers on tomato 508 and cucumber seedlings They indicated that application of these fertilizers had a positive effect 509 on dry shoot weight, which can be attributed to the positive effect of organic matter on the 510 physical properties and nutrient status of the soil.

511 Due to its nutrients and porous structure, specific surface, and strong functional groups, biochar 512 is anion that can increase crop yield by improving soil nutrients and physical and chemical 513 propertiesv(Xiang et al. 2017). The application of manure and biochar provided suitable 514 conditions in terms of nutritional balance for plants, so that plant growth and yield increased 515 significantly under these treatments, which is consistent with the results of other studies. Ahmad 516 et al. (Ahmad et al. 2014). Investigated the effect of biochar application on the biomass of maize 517 (Zea mays L.) and reported a significant increase in plant biomass compared to the control 518 sample. Also, Lehmann and Joseph (Lehmann et al. 2009). reported argued adding biochar to the 519 soil would preserve nutrients and thus increase plant growth, which is consistent with the results 520 of the present study so that we observed that amending compounds led to increased growth of the 521 two species of $S$. persica and S. perspolitana. 


\subsection{Accumulation of chromium in the roots and shoots of S. persica and S. perspolitana}

523 This study showed that the accumulation of chromium in the roots and shoots of both species

524 increased with increasing the chromium concentration in the soil. Most of the chromium

525 accumulation occurred in the roots, which is consistent with the findings of Shahid et al.(Shahid

526 et al. 2017). who stated that in Pisum sativum, the chromium concentration in different parts of

527 the plant was as following: root > stem > leaf > seed. Liu et al.(Liu et al. 2009). observed the

528 highest concentration of chromium in the root cell wall and intercellular spaces of the rhizome.

529 Chromium fixation in plant roots is probably due to the formation of insoluble chromium

530 compounds in the plant. Some authors have reported that chromium storage in root cells may be

531 increased due to its storage in vacuoles of root cells, which may be a plant reaction to heavy

532 metal toxicity to limit the toxic potential of the heavy metals(Shahid et al. 2017). In the present

533 study, the effect of different chromium concentrations on the chromium accumulation in the two

534 studied species at different concentrations of $0,5,10,15$ was significantly different, so that the 535 accumulation of chromium in the shoots for both species increased with increasing chromium

536 concentration in the soil. Also, chromium accumulations in the shoots were significantly

537 different among the experimental treatments. During plant growth and development, higher

538 chromium accumulation was observed for the roots. Higher accumulation of chromium in the

539 roots compared to the shoots is a characteristic phenomenon observed in crops. Brunetti et

540 al.(Brunetti et al. 2011). stated that higher accumulation of chromium, copper, lead, and zinc in

541 the roots than the shoots represents the mechanism of plant tolerance and adaptation to high

542 concentrations of metals in the soil. Singh et al.(Singh et al. 2004) attributed the higher

543 accumulation of heavy metals in the roots than that of the shoot to the complexation of these

544 metals with sulfhydryl groups, which prevented the transfer of these metals to the shoot. This 
545 prevents the transfer of heavy metals to the food chain. Although the transfer of chromium from 546 the plant roots to the shoots is minimal, the transfer of chromium within the plant tissue depends 547 on its chemical form. The decreased chromium transport to plant shoots may be due to the 548 conversion of hexavalent to trivalent chromium within plants due to the tendency of trivalent 549 chromium to attach to cell walls. As shown in table 7, trivalent chromium has a higher tendency 550 to be absorbed into the plant than hexavalent form, which may indicate the ability of Salicornia 551 to convert hexavalent chromium to trivalent form in its tissues. In terms of growth, the plant 552 needs to absorb trivalent chromium.

553 Also, the results obtained from this study showed that the amendments negatively influenced on 554 the accumulation of chromium in the roots and shoots in both species. The highest decrease in 555 chromium uptake was observed in biochar treatment. Biochar can be applied as an effective 556 amendment for stabilizing heavy metals in contaminated soils. Namgay et al.(Namgay et al. 557 2010). showed that adding biochar as an amendment to soils contaminated with heavy metals 558 could reduce the availability and absorption of these metals in plants. Zheng et al.(Zheng et al. 559 2012) also demonstrated that cadmium concentration in rice roots (Oryza sativa L.) decreased 560 after the application of biochar.

561 The addition of manure to the soil also resulted in decreased uptake of chromium compared to 562 soil without amendment. By increasing the cation exchange capacity of the soil, manure's 563 application can be effective in reducing the availability of heavy metals in soil and plants. 564 Containing a large amount of humus, manure's addition to the soil can alter the availability of 565 heavy metals by changing soil physical and chemical properties(Pinto et al. 2004). Antoniadis et 566 al.(Antoniadis et al. 2017) proved that the addition of manure would lead to reduced 567 bioavailability of chromium in the chicory (Cichorium spinosum) and serves as the best way for 
568 minimizing the toxic effect of chromium on the plant. Therefore, adding manure may be the

569 most appropriate option for the stabilization of hexavalent chromium to inhibit the absorption of

570 this heavy metal by the plant. As a result, manure's addition leads to decreased bioavailability of

571 hexavalent chromium and slows down the phytoremediation process.

\subsection{The effect of chromium toxicity on total phenolic content and photosynthetic pigments}

573 The results of the present study showed that total phenolic content and photosynthetic pigments

574 significantly decreased as a result of heavy metal toxicity. This decrease was greater in $S$.

575 perspolitana than in S. persica and probably due to the higher accumulation of the metal in $\mathrm{S}$.

576 perspolitana. Also, the organic compounds (biochar and manure) caused an increase in the

577 number of photosynthetic pigments with the higher contribution for biochar than manure, which

578 can be explained by biochar's effect on increasing growth and reducing the accumulation of

579 heavy metals in the plant. The non-enzymatic defense system of plants produces phenolic

580 compounds, and these antioxidant compounds react with free radicals and convert them to stable

581 radicals by giving up electrons to free radicals (Falleh et al. 2012).

582 In the present study, different chromium concentrations strongly affected the phenolic content of 583 the plant, so that the accumulation of chromium at the concentration of $15 \mathrm{mg} / \mathrm{kg}$ completely 584 suppressed the antioxidant properties of the plant, and the weakened defense system resulted in 585 decreased plant growth. Levizou et al.(Levizou et al. 2019) showed that the total phenolic 586 content in the marjoram plant (Origanum vulgare) decreased with the increasing chromium in 587 the soil. Islam et al.(Islam et al. 2016).

588 Attributed the decreased phenolic content to the malfunctioning of critical enzymes in the 589 biosynthesis of these compounds, which was consistent with the results of the present study 590 regarding the effect of chromium stress on reducing phenolic content. 
591 In addition to inhibiting chlorophyll biosynthesis due to the presence of heavy metals, Dhir et

592 al.(Dhir et al. 2008) reported a decrease in iron and magnesium in the chlorophyll structure as a

593 possible reason for the decrease in chlorophyll efficiency. In the present study, the contents of

594 chlorophyll a and b significantly decreased under the effect of metal chromium compared to

595 control plants, which is consistent with the findings of other studies.

596 Carotenoids are lipophilic secondary metabolites and the second most abundant pigment in 597 nature. While chlorophylls are classified as optical pigments, carotenoids in stressful situations 598 mainly contribute to protect the chlorophyll photosynthetic system. To quench the photodynamic 599 reactions that can lead to chlorophyll loss, carotenoids replace peroxides to prevent the 600 chloroplast membrane from collapsing (Duarte et al. 2012). The results of our study showed that 601 chlorophyll $a, b$, and carotenoids contents in the shoots of both S. persica and S. perspolitana 602 decreased with increasing the chromium concentration in the soil, confirming the results reported 603 by many authors regarding the effect of chromium on plant pigments such as maize (Zea mays cv 604 704)(Rahmaty \&Khara 2011) and wheat (Triticum aestivum L) (Subrahmanyam 2008).

\subsection{The effect of Salicornia on the phytoremediation process}

606 The results of phytoremediation in the present study showed that S. persica and S. perspolitana 607 were able to absorb heavy metals from the soil with higher uptake of metals in the roots than 608 shoots for both species. Considering that the TF index was lower than 1 for all treatments, one 609 can conclude that $S$. persica and $S$. perspolitana were not suitable for phytoextraction of metal 610 chromium. Also, the BCF factor for metal chromium was higher than 1, indicating that both $S$. 611 persica and $S$. perspolitana stabilize the metal in the soil during the stabilization process. Both 612 species mostly absorb trivalent form of chromium, indicating the high efficiency for converting 613 hexavalent to trivalent form. 
614 Yoon et al. (Yoon et al. 2006) found that plants with high accumulation and low transfer factors

615 can stabilize heavy metals. Plant species that have been used to stabilize heavy metals so far

616 include Festuca rubra (lead and zinc) and Brassica juncea (cadmium) (Ghosh \&Singh 2005),

617 which is consistent with our findings in this research.

\section{5. Conclusions}

619 This study aimed to investigate the accumulation capacity of chromium metal in shoots and roots 620 of S. persica and S. perspolitana. In this study, manure and biochar amendments were used to

621 immobilize and stabilize metal chromium in contaminated soils. Chromium concentration in

622 shoots and roots in $S$. persica and $S$. perspolitana were significantly affected by the 623 concentration of this metal in the soil. In all observations, chromium accumulation in shoots and 624 roots of the two studied species increased with increasing soil metal concentration. Both $S$. 625 persica and $S$. perspolitana can be used for phytoremediation of soils contaminated with low 626 concentrations of chromium as these two species could not tolerate the accumulation of 627 chromium at high concentrations. The results also indicated higher chromium accumulations in

628 the roots than the shoots for both $S$. persica and $S$. perspolitana species. Therefore, these two 629 species can change the rhizosphere environment of the root and influence on concentration and 630 bioavailability of metal chromium. The results of the present study showed a characteristic 631 feature of converting hexavalent to trivalent chromium for both studied species. Accumulation of 632 total chromium, trivalent chromium, and hexavalent chromium in the shoots was higher in $S$. 633 persica than S. perspolitana. The photosynthetic pigments and total phenolic content in both 634 studied species also decreased with increasing chromium concentration.

635 Our findings also showed that the use of organic compounds could improve the growth and yield 636 of $S$. persica and $S$. perspolitana and, at the same time, decrease accumulation of chromium in 
637 roots and shoots. Application of biochar and manure in S. persica and S. perspolitana species in 638 the reclamation of soils contaminated with heavy metals caused increases of $49.05 \%$ and $28.30 \%$ 639 in dry shoot weight, $53.12 \%$ and $14.06 \%$ in root dry weight, $23.93 \%$, and $13.29 \%$ in chlorophyll $640 a, 22.72 \%$ and $13.63 \%$ in chlorophyll $b$ and $16.93 \%$ and $6.92 \%$ in carotenoids content compared 641 to the controls (without amendment). Biochar and manure treatments also reduced the total 642 phenolic content by $11.83 \%$ and $13.12 \%$ in S. persica and S. perspolitana, respectively. Biochar 643 and manure treatments caused decreases by $36.69 \%$ and $17.98 \%$ in accumulation of metal 644 chromium in the roots, and $84.83 \%$ and $72.55 \%$ in the shoots, respectively, compared to controls 645 (without amendment). In general, the application of biochar treatment had a greater effect on 646 reducing the accumulation of heavy metals than manure treatment because biochar has a higher

647 ability to absorb metals due to its porous structure. As a result, it reduces the bioavailability of 648 metals in both species. Therefore, using organic amendments in soils contaminated with heavy 649 metals can stabilize these metals in the soil and prevent entering them into the food chain.

650

651 Acknowledgments

652 The authors would like to thank the Ferdowsi University of Mashhad for its financial support ( 653 Grant number: 47716) for this research.

654

655 Ethics approval and consent to participate: "Not applicable"

656 Consent for publication: "Not applicable"

657 Availability of data and materials: The datasets used and/or analyzed during the current study are 658 available from the corresponding author on reasonable request.

659 Competing interests: "The authors declare that they have no competing interests".

660 Funding: This study was funded by the Ferdowsi University of Mashhad (47728) of Iran. 
Authors' contributions:

662 Fahime Ashrafi: Investigation, Project administration, Resources, Validation Writing - original 663 draft, Software, Formal analysis, funding acquisition.

664 Ava Heidari: Supervision, Visualization, Writing - review \& editing, Conceptualization, Data 665 curation, Methodology, Project administration, Funding acquisition.

666 Mohammad Farzam: Supervision, Data curation, Validation.

667 Alireza Karimi: Supervision, Data curation, Validation.

668 Malihe Amini: Writing - review \& editing, Formal analysis, Validation

669

670

671

672

673

674

675

676

677

678

679

680

681

682

683

684

685

686

687

688

689

690

691

692

693

694

695

696

Refrences

Ahmad M, Lee SS, Lim JE, Lee S-E, Cho JS, Moon DH, Hashimoto Y, Ok YSJC (2014): Speciation and phytoavailability of lead and antimony in a small arms range soil amended with mussel shell, cow bone and biochar: EXAFS spectroscopy and chemical extractions. 95, 433-441

Al-Wabel MI, Usman AR, El-Naggar AH, Aly AA, Ibrahim HM, Elmaghraby S, Al-Omran AJSjobs (2015): Conocarpus biochar as a soil amendment for reducing heavy metal availability and uptake by maize plants. 22, 503-511

Amin H, Arain BA, Amin F, Surhio MAJAJoPS (2013): Phytotoxicity of chromium on germination, growth and biochemical attributes of Hibiscus esculentus L. 2013

Antoniadis V, Polyzois T, Golia EE, Petropoulos SAJC (2017): Hexavalent chromium availability and phytoremediation potential of Cichorium spinosum as affect by manure, zeolite and soil ageing. $171,729-734$

Bashir S, Hussain Q, Akmal M, Riaz M, Hu H, ljaz SS, Iqbal M, Abro S, Mehmood S, Ahmad MJJos, sediments (2018): Sugarcane bagasse-derived biochar reduces the cadmium and chromium 
bioavailability to mash bean and enhances the microbial activity in contaminated soil. 18,874 886

Bhalerao SA, Sharma ASJIJCMAS (2015): Chromium: as an environmental pollutant. 4, 732-746

Bhardwaj P, Chaturvedi AK, Prasad PJN, science (2009): Effect of enhanced lead and cadmium in soil on physiological and biochemical attributes of Phaseolus vulgaris. 7, 63-75

Brunetti G, Farrag K, Rovira PS, Nigro F, Senesi NJG (2011): Greenhouse and field studies on Cr, Cu, Pb and $\mathrm{Zn}$ phytoextraction by Brassica napus from contaminated soils in the Apulia region, Southern Italy. 160, 517-523

Coupe SJ, Sallami K, Ganjian EJAJoB (2013): Phytoremediation of heavy metal contaminated soil using different plant species. $12,6185-6192$

Dhir B, Sharmila P, Saradhi PPJBJoPP (2008): Photosynthetic performance of Salvinia natans exposed to chromium and zinc rich wastewater. 20,61-70

Díaz J, Bernal A, Pomar F, Merino FJPS (2001): Induction of shikimate dehydrogenase and peroxidase in pepper (Capsicum annuum L.) seedlings in response to copper stress and its relation to lignification. 161, 179-188

Duarte B, Silva V, Caçador IJE, safety e (2012): Hexavalent chromium reduction, uptake and oxidative biomarkers in Halimione portulacoides. 83, 1-7

Edao HGJIJAR (2017): Heavy metals pollution of soil; toxicity and phytoremediation techniques. 1, 29-41

Evangelou MW, Bauer U, Ebel M, Schaeffer AJC (2007): The influence of EDDS and EDTA on the uptake of heavy metals of $\mathrm{Cd}$ and $\mathrm{Cu}$ from soil with tobacco Nicotiana tabacum. 68, 345-353

Falleh H, Ksouri R, Lucchessi M-E, Abdelly C, Magné CJTJoPR (2012): Ultrasound-assisted extraction: Effect of extraction time and solvent power on the levels of polyphenols and antioxidant activity of Mesembryanthemum edule L. Aizoaceae shoots. 11, 243-249

Ghani WAWAK, Mohd A, da Silva G, Bachmann RT, Taufiq-Yap YH, Rashid U, Ala'a HJIC, Products (2013): Biochar production from waste rubber-wood-sawdust and its potential use in $\mathrm{C}$ sequestration: chemical and physical characterization. 44, 18-24

Ghosh M, Singh SJAJEE (2005): A review on phytoremediation of heavy metals and utilization of it's by products. 6, 18

Islam F, Yasmeen T, Arif MS, Riaz M, Shahzad SM, Imran Q, Ali IJPP, Biochemistry (2016): Combined ability of chromium (Cr) tolerant plant growth promoting bacteria (PGPB) and salicylic acid (SA) in attenuation of chromium stress in maize plants. $108,456-467$

Kamran M, Eqani S, Katsoyiannis A, Xu R, Bibi S, Benizri E, Chaudhary HJJGE (2017): Phytoextraction of chromium ( $\mathrm{Cr}$ ) and influence of Pseudomonas putida on Eruca sativa growth. 182, 269-274

Lehmann J, Joseph SJBfemS, technology (2009): Biochar for environmental management: an introduction. 1, 1-12

Levizou E, Zanni AA, Antoniadis VJES, Research P (2019): Varying concentrations of soil chromium (VI) for the exploration of tolerance thresholds and phytoremediation potential of the oregano (Origanum vulgare). 26, 14-23

Liu J, Duan C-Q, Zhang X-H, Zhu Y-N, Hu CJP, soil (2009): Subcellular distribution of chromium in accumulating plant Leersia hexandra Swartz. 322, 187-195

Lukina A, Boutin C, Rowland O, Carpenter DJC (2016): Evaluating trivalent chromium toxicity on wild terrestrial and wetland plants. 162, 355-364

Moameri M, Jafri M, Tavili A, Motasharezadeh B, Zare Chahouki MJJoRS (2017): Rangeland plants potential for phytoremediation of contaminated soils with lead, zinc, cadmium and nickel (case study: Rangelands around National Lead \& Zinc Factory, Zanjan, Iran). 7, 160-171

Murtaza S, Iqbal MZ, Shafiq M (2018): EFFECTS OF CHROMIUM ON SEED GERMINATION AND SEEDLING GROWTH OF MUNG BEAN VIGNA RADIATA (L.) R. WILCZEK (FABACEAE). 
Namgay T, Singh B, Singh BPJSR (2010): Influence of biochar application to soil on the availability of As, $\mathrm{Cd}, \mathrm{Cu}, \mathrm{Pb}$, and $\mathrm{Zn}$ to maize (Zea mays L.). 48, 638-647

Park C-H, Li XR, Zhao Y, Jia RL, Hur J-SJPO (2017): Rapid development of cyanobacterial crust in the field for combating desertification. 12, e0179903

Peralta J, Gardea-Torresdey J, Tiemann K, Gomez E, Arteaga S, Rascon E, Parsons JJBoEC, toxicology (2001): Uptake and effects of five heavy metals on seed germination and plant growth in alfalfa (Medicago sativa L.). 66, 727-734

Pinto A, Mota Ad, De Varennes A, Pinto FJSotte (2004): Influence of organic matter on the uptake of cadmium, zinc, copper and iron by sorghum plants. 326, 239-247

Rahmaty R, Khara JJTJoB (2011): Effects of vesicular arbuscular mycorrhiza Glomus intraradices on photosynthetic pigments, antioxidant enzymes, lipid peroxidation, and chromium accumulation in maize plants treated with chromium. $35,51-58$

Saberi M, Tavili A, JAFARI M, HEYDARI M (2010): The effects of different levels of heavy elements on germination and growth of Atriplex lentiformis.

Shahandeh H, Hossner LIjop (2000): Plant screening for chromium phytoremediation. 2, 31-51

Shahid M, Shamshad S, Rafiq M, Khalid S, Bibi I, Niazi NK, Dumat C, Rashid MIJC (2017): Chromium speciation, bioavailability, uptake, toxicity and detoxification in soil-plant system: a review. 178, 513-533

Shanker AK, Cervantes C, Loza-Tavera H, Avudainayagam SJEi (2005): Chromium toxicity in plants. 31, 739-753

Singh S, Saxena R, Pandey K, Bhatt K, Sinha SJC (2004): Response of antioxidants in sunflower (Helianthus annuus L.) grown on different amendments of tannery sludge: its metal accumulation potential. 57, 1663-1673

Subrahmanyam DJP (2008): Effects of chromium toxicity on leaf photosynthetic characteristics and oxidative changes in wheat (Triticum aestivum L.). 46, 339

Sundaramoorthy P, Chidambaram A, Ganesh KS, Unnikannan P, Baskaran LCrb (2010): Chromium stress in paddy:(i) nutrient status of paddy under chromium stress;(ii) phytoremediation of chromium by aquatic and terrestrial weeds. 333, 597-607

Van Oosten MJ, Maggio AJE, botany e (2015): Functional biology of halophytes in the phytoremediation of heavy metal contaminated soils. 111, 135-146

Xiang Y, Deng Q, Duan H, Guo YJGb (2017): Effects of biochar application on root traits: a meta-analysis. 9, 1563-1572

Yao Z, Li J, Xie H, Yu CJPES (2012): Review on remediation technologies of soil contaminated by heavy metals. $16,722-729$

Yoon J, Cao X, Zhou Q, Ma LQJSotte (2006): Accumulation of $\mathrm{Pb}, \mathrm{Cu}$, and $\mathrm{Zn}$ in native plants growing on a contaminated Florida site. 368, 456-464

Zebarth B, Neilsen G, Hogue E, Neilsen DJCJoSS (1999): Influence of organic waste amendments on selected soil physical and chemical properties. 79, 501-504

Zheng R-L, Cai C, Liang J-H, Huang Q, Chen Z, Huang Y-Z, Arp HPH, Sun G-XJC (2012): The effects of biochars from rice residue on the formation of iron plaque and the accumulation of $\mathrm{Cd}, \mathrm{Zn}, \mathrm{Pb}$, As in rice (Oryza sativa L.) seedlings. $89,856-862$ 


\section{Figures}
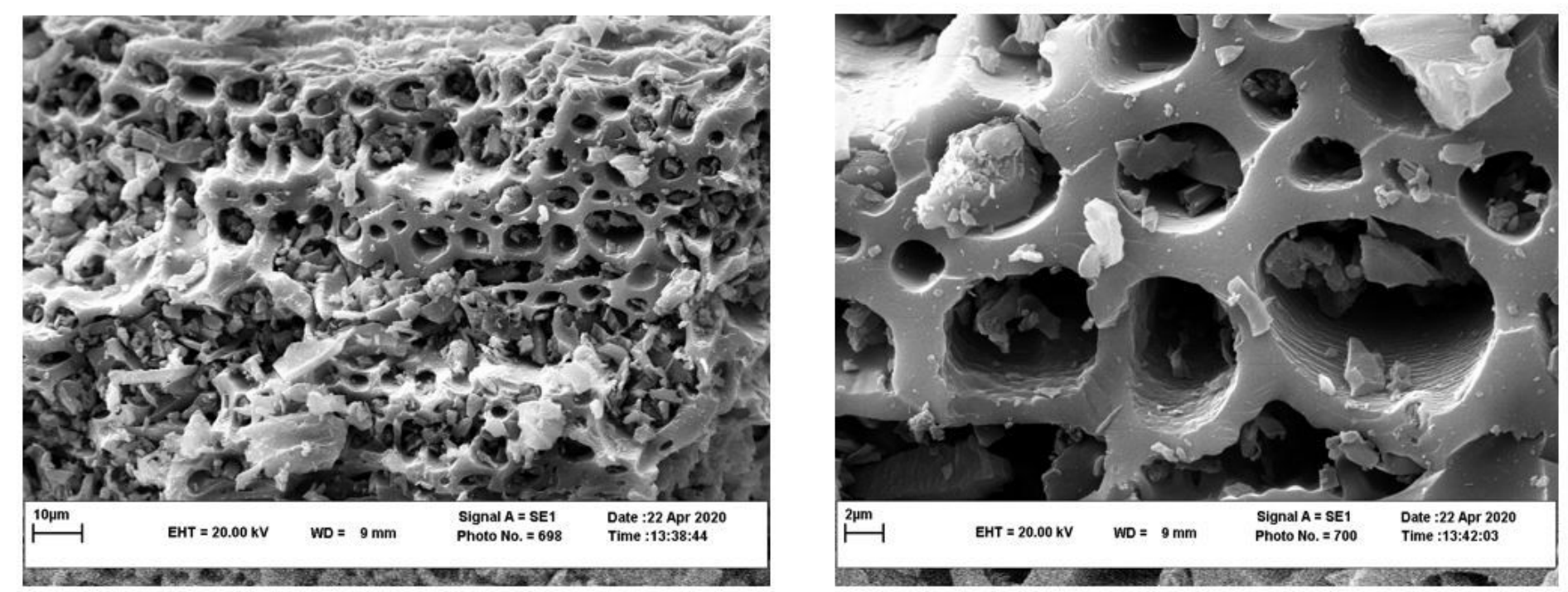

\section{Figure 1}

Scanning electron microscopy (SEM) of biochar surface 